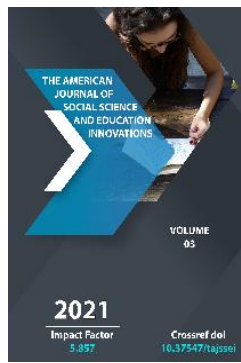

\title{
Postal Service During Second World War (1941-1945)
}

\author{
Rufina Ravilevna Kayumova \\ Basic Doctoral Student Of Andizhan State University Named After Babur, Andizhan Region, \\ Republic Of Uzbekistan
}

\begin{abstract}
Journal Website:
https://theamericanjou

rnals.com/index.php/ta

jssei

Copyright: Original content from this work may be used under the terms of the creative commons attributes 4.0 licence.
\end{abstract}

\section{ABSTRACT}

The article examines the problems of the organization and the results of the work of the postal service during the Second World War, and also reveals the forms of postage and writing materials as an important characteristic of private correspondence between the front and rear.

\section{KEYWORDS}

World War II, State Defense Committee, military field mail, postal workers, envelopes, letters, censorship, postcards.

\section{INTRODUCTION}

On May 9, all our multinational people celebrate the Day of Remembrance and Honor. Celebrating this glorious date, we always feel both great joy and endless pain at the same time. We honor the bright memory of our fathers and grandfathers, who showed real heroism in battles and selflessly worked in the rear for the sake of the freedom of our Motherland, of today's peaceful days. As the President of the Republic of Uzbekistan Shavkat Mirziyoyev noted at the celebration dedicated to the 76th anniversary of the Great
Victory in World War II, "No matter how many years, centuries pass, our people will always keep in their hearts the memory of your courage in the fight against fascism. It is on the example of the highest heroism of our fathers and grandfathers that the main values of the people and the nation are formed and further developed. Over time, much is forgotten - this is the law of life. However, in this world there is one great, immutable truth: courage and courage in the name of freedom of the Motherland, peace and happiness of future 
generations will forever remain in the memory of the people "[1,1].

\section{METHODS}

Since the first days of World War II, when most of the male population left their homes and joined the ranks of the Soviet Army, the postal service became the only thread that made it possible to get at least some news from home. The government was well aware that in order to maintain the emotional spirit of the soldiers at the proper level, it is necessary to ensure the uninterrupted operation of the mail. According to eyewitnesses, the letter delivered from home on time was much more important for the soldiers than the field kitchen and other modest benefits of front-line life. And thousands of women across the country watched the postmen for hours in the hope that they would finally bring them word from their husbands, sons and brothers.

In the first weeks of the war, postal workers faced the common problem of a shortage of envelopes. It was then that letters-triangles, folk letters, appeared, when a sheet with a letter was simply folded several times, and the recipient's address was written on the upper side. The Soldier's Triangle is the most widespread type of dispatch. Finely written and folded in three paper sheets solved the problem of an acute shortage of envelopes. These famous symbols of hope and a strong front-to-rear connection have often been referenced by writers on World War II.

\section{RESULTS AND DISCUSSIONS}

The triangle letter was a rectangular sheet of paper folded first from right to left and then from left to right. The remaining strip of paper was inserted inside. The stamp was not required the letter was not sealed, since everyone knew that it would be read by censorship. On the outside, the destination address and the return address were written, and a clean place was left for the postal workers' marks. Since notebooks were worth their weight in gold, the message was written in the smallest handwriting, filling all the usable space. Such letters-triangles were folded even by small children, who were constructing a message to a folder from an ordinary piece of newspaper. A postcard (the address part, postage marks and an illustration are on one side, and the second is completely intended for writing) and a postcard (one side is filled with an illustration, and the address part is placed on the second on the right, and a place for writing on the left).

If the addressee had already died by the time the letter was delivered, then they made a note of the death on the triangle, crossed out the destination address and returned it back. Often, such a triangle replaced the "funeral". In rare cases, when the addressee was listed as missing or was shot for cowardice, the letter was destroyed. If a soldier was transferred to another unit, ended up in an infirmary or hospital, then a new address was put on the spot for notes. Some of these forwarded letters disappeared for a long time, finding an addressee only years after the war.

It is also interesting that during the war years, letters to the front sometimes reached the front faster than in our days. This was due to the fact that the People's Commissar of Communications achieved exceptional conditions for the delivery of army mail. No matter how tightly the railway was swirled, postal trains were allowed through in the first place, and their stops were considered unacceptable. In addition, mail was transported using all available means of transport, depending on local conditions - in special mail cars, ships, mail planes, cars and even motorcycles. The use of postal transport for any other needs was strictly prohibited. Along with the combat support of the army, military postal cargo was given priority. In a number of areas, carrier pigeons were used to deliver mail, which freely carried secret messages across the front line in places where 
the plane could never fly unnoticed. German snipers even tried to shoot the unfortunate birds, groups of special hawks were released to destroy them, but most of the carrier pigeons, nevertheless, managed to successfully deliver information to their destination. To reduce the possibility of detection, Soviet scientists have developed a special breed of carrier pigeons that can fly at night.

The main number of postmen or forwarders, as they were officially called then were men. This was no coincidence, since the total weight of the cargo that they had to carry, in addition to the usual uniforms, consisted of many letters and newspapers and was almost equal to the weight of a machine gun. However, the weight of the cherished bag of the postman was measured not by kilograms of letters, but by human emotions and tragedies that came with them. The appearance of the postman in every house was both expected and feared, because the news could be not only good, but also tragic. Letters in the rear became practically messengers of fate, each of them contained the answer to the most important question - is the one who is expected and loved alive? This situation imposed a special responsibility on the news carrier, every postman had to experience both joy and grief along with his addressees every day.

An interesting phenomenon that became widespread among the soldiers was the "scribes". Not all servicemen could competently and beautifully write a letter to their beloved girlfriend or mother. Then they turned to more trained and educated comrades for help. In each part, there were recognized and respected specialists from whom you could take a sample of the letter or ask them to dictate its text live. The value of the front-line letters lies in the fact that in a comprehensive study of the social aspects of the history of the war, they not only complement the eventual moments, but also allow one to assess the consciousness, worldview and sensory-emotional perception of a person - a participant and eyewitness of military events.

Despite the difficult trials of the war years, the archival service of the Republic of Uzbekistan paid special attention to the acquisition of event archival funds. Since 1942, archivists have done a lot of work to collect and form a separate archival fund for collections of letters from the front. On the basis of the collected letters from the period of the war in the National Archives of Uzbekistan, a special fund $\mathrm{P}-1735$ "Collection of letters from the fronts of the Patriotic War (1941-1945)" was formed [2.1]. The archival inventory of the fund was compiled in 1948. In total, the fund contains about 5 thousand letters sent to various editorial offices of newspapers, institutions and individuals, friends, relatives and acquaintances. The collection includes letters from front-line soldiers to such editorial offices of newspapers as "Red Uzbekistan", "Pravda Vostoka", "Frunzovets", "Khorezm Pravda" [3.76] and others. It also contains letters sent to the Uzradiocommittee, to the land management department People's Commissariat of Agriculture of the UzSSR, to Hydroenergoproekt, to workers of factories and plants, etc. In addition, the collection contains private front-line correspondence of various persons with their relatives, friends and acquaintances.

Since the beginning of the war, letters to the front were sent to the number of the field mail, the number of the military unit and the last name, first name, patronymic of the addressee. On September 5, 1942, the open name of the unit was replaced with a conditional number. From February 6, 1943, by order of the People's Commissar of Defense, five-digit numbers of field mails were introduced and items were addressed only to this number and the last name, first name, patronymic of the addressee. [4.165]. It was forbidden to indicate the location of the unit, its actual name, as well as military rank, position and the specialty of the addressee. By the end of 1941, the military post 
office was already functioning as a well-oiled mechanism. Up to seventy million letters were delivered to the front every month [5.78]. The employees of the postal sorting points worked around the clock to avoid interruptions and delays. However, they sometimes did happen if the military unit retreated or was surrounded. It also happened that letters died along with the post trains or disappeared into the bag of the postman who was killed during their delivery. But in most cases, every effort was made to ensure that each letter reached its addressee as quickly as possible.

As the troops moved westward, it was necessary to restore postal communication in each conquered area. Fortunately, during the war years, the mechanism was worked out to perfection, and most importantly, there were high-class communication specialists. After the Red Army crossed the border of the USSR on December 1, 1944 and the war was already drawing to a close, the State Defense Committee adopted a special resolution, according to which all servicemen of the active army were allowed to send a parcel of the established weight home once a month. In just four months of 1945, the mail was able to deliver ten million parcels to the rear of the country, for the transport of which it took more than ten thousand two-axle mail cars.

At the very beginning of the war, in order to preserve state secrets, the State Defense Committee was forced to introduce military censorship, the issue of preserving state secrets, preventing the spread of all sorts of anti-Soviet, defeatist, provocative and slanderous messages that undermined the defense capability and state security through postal and telegraph communications countries. All mail was carefully checked, censorship was total, the number of censors doubled, and there were at least ten political controllers for each army. The inspectors were interested not only in the data contained in the letters about the deployment of units and their numbers, the names of commanders and the number of casualties, but also the emotional mood of the soldiers of the active army. Every letter or postcard had this stamp: black or blue, square. The fact is that during the Second World War, postal military censorship worked hard. She monitored all correspondence of the military in order to prevent the publication of information containing military secrets.

For this purpose, the State Defense Committee issues a decree "On measures to strengthen the political control of postal and telegraph correspondence" dated July 6, 1941 [6.77]. In connection with the military situation in the country, in order to suppress the disclosure of state and military secrets and prevent the dissemination of all kinds of anti-Soviet, provocative-slanderous and other messages through postal and telegraph communication, aimed at the detriment of the state interests of the Soviet Union, the State Defense Committee of the USSR decided, on the prohibition of messages in letters and telegrams of any information of a military, economic or political nature, the publication of which may harm the state; on the prohibition of receiving and sending postcards with views and pasted photographs, letters with a font for the blind, crosswords, chess tasks, etc .; and it was also determined that letters should not exceed four pages of stationery. Clause 2 of this document obliged the People's Commissariat of State Security of the USSR to organize $100 \%$ of the viewing of letters and telegrams ... for which to allow the NKGB of the USSR to increase the staff of political controllers accordingly. And further, in the regions declared under martial law, introduce military censorship on all incoming and outgoing postal and telegraphic items [7.103]. The implementation of military censorship was entrusted to the organs of the NKGB and third departments of the NCO and NKMF. The opened and examined documents bore the stamp "Viewed by the military censorship." The private life of citizens even before the war was the subject of close state control, and wartime did not affect the current state of 
affairs in any way. The private correspondence of family members was no longer their personal affair. It is no coincidence that postal censorship during the war years was directly subordinate to SMERSH, the Main Directorate of Counterintelligence in the USSR People's Commissariat of Defense.

One of the "softest" types of postal censorship was the deletion of lines containing information that was unacceptable for transmission in the opinion of the inspectors. Obscene expressions, criticism of the army order and any negative statements about the situation in the army were crossed out.

It should be noted that military censorship was formed in the 19th century, and its main task was to preserve military secrets, and the list of information related to classified information was huge. For example, data on the number of military personnel, explosions, fires, unrest in military units, and much more. Military censors were forbidden to delay letters for more than 24 hours. They were required to open letters with extreme caution! The slightest (zeal) and blackouts were strictly prohibited. And letters containing prohibited information were subject to confiscation.

And fortunately, most of the letters reached their addressees. The country's leadership understood how important it is to maintain the emotional spirit of the fighters at the proper level to ensure the uninterrupted operation of the mail. The bulk of the soldiers were driven not only by the desire to defend their homeland and free it from the hated occupiers, but also by the desire to protect the most dear people who remained somewhere far in the rear or in the territory already occupied by the enemy.

With undisguised delight, the authors of the letter rejoiced at each new message: "Write more often, dear. You say it yourself, now this is your main job", "I received your 3 greeting cards the other day. Thank you for your concern ..." [8, p.87] Many letters reflect a healthy political and moral state of the army units, a high spirit of patriotism, devotion to the Motherland and readiness to fight against fascism until the complete defeat of the German army. It is important that the letters of the soldier to his relatives, letters and parcels to the soldiers, which come in a huge stream from all over the country, are not delayed due to the fault of the communications workers. Each such letter, each such package in the name of fathers and mothers, brothers and sisters, relatives and friends, in the name of the entire Soviet people infuse new forces into the fighter, inspire him to new deeds ... such a message could often be seen in the periodicals of that period. During the war years, all correspondence sent to the front and rear was free. The exception was parcels. Machines intended for the transportation of correspondence could not be used for other purposes, and mail cars were allowed to be attached to any trains, since they had no less priority than cars with ammunition.

It should be noted that the State Defense Committee, by its resolutions №7054 of December 1, 1944 and №7192 of December 23, 1944 [9, p.1], allowed the Red Army men, sergeants and officers, and generals of the active fronts to perform well sending personal parcels to your home. Parcels were sent no more than once a month in sizes: for privates and sergeants - $5 \mathrm{~kg}$, for officers - $10 \mathrm{~kg}$ and for generals $-16 \mathrm{~kg}$.

\section{CONCLUSION}

Each news from the front covered the following path: every day the postman took letters from the soldiers out of the mailbox of the military unit and took them to the military post station. Here, letters were stamped with dates, put in large bags and sent to the military postal base. There the letters were sorted by directions and then transferred to the military postal sorting point for further mailing to addresses. The letter from the rear passed the 
way back and reached the field post station, from where the postman carried it to the addressee, including to the front line. After the act of surrender was signed by Germany on May 8 at 22.43 European time, the post had to endure one more last "battle". A tsunami of congratulatory letters and postcards literally swept all the post offices of our country. People were in a hurry to share their joy with the whole world. Sometimes it was simply impossible to cope with such a powerful flow, and mountains of unsorted letters accumulated at post stations, reaching the addressees with great delay. However, as life gradually began to return to a peaceful course and new post-war worries and problems appeared, postmen ceased to be objects of general attention, and when they appeared, people did not fall silent in anticipation of the unknown.

\section{REFERENCES}

1. Speech by the President of the Republic of Uzbekistan Shavkat Mirziyoyev at the solemn ceremony dedicated to the 76th anniversary of the Great Victory and the Day of Memory and Honor // Narodnoe Slovo. - T., 2021.- May 10, No. 97 (7846) .-p.1.

2. National Archives of Uzbekistan, fund R1735, list 1, work -136 .

3. Shamsutdinov R. On the contribution of the people of Uzbekistan to the great victory (1941-1945). -Tashkent: Akademnashr, 2020. (In Uzbek)

4. The Great War 1941-1945: photo album / V. I. Chuikov, V. S. Ryabov. - M.: Planeta, 1987 .$-391 \mathrm{p}$.

5. Letters from the participants of the Great Patriotic War of 1941-1945 / V.A. Somov /I Questions of history-2003.-№ 8.

6. Eve and the beginning of the war: Documents and materials / comp. L.A. Kirshner. - L.: Lenizdat, 1991 .-431 p.

7. Uzbek SSR during the Great Patriotic War (1941-1945) edit. R.Kh. Aminova, T. D. Zhuraev, T., Fan, 1966, 254 p.
8. National Archives of Uzbekistan, fund R1735, list.1, work-6, p.87.

9. Russian State Archive of Social and Political History, Fund.644, list 1, work-1l, p. 127-128. 